\section{Phlebotomine sandfly species from an American visceral leishmaniasis area in the Northern Rainforest region of Pernambuco State, Brazil}

\author{
A fauna de flebotomíneos envolvida em área de \\ incidência de leishmaniose visceral americana na \\ Zona da Mata de Pernambuco, Brasil
}

\author{
${ }_{1}$ Centro de Pesquisas Aggeu \\ Magalhães, Fundação \\ Oswaldo Cruz, Recife, Brasil. \\ 2 Fundação Nacional de \\ Saúde, Recife, Brasil. \\ Correspondence \\ S. P. Brandão-Filho \\ Centro de Pesquisas \\ Aggeu Magalhães, \\ Fundação Oswaldo Cruz. \\ Av. Moraes Rego $s / n$ \\ Recife, $P E$ \\ 50670-420, Brasil. \\ sinval@cpqam.fiocruz.br
}

\begin{abstract}
The aim of this study was to identify the fauna of phlebotomine sandflies in an area with incidence of American visceral leishmaniasis (AVL) in São Vicente Férrer, a municipality (county) located in the northern Zona da Mata in Pernambuco State, Brazil. Sandfly captures were conducted monthly for four nights/month from December 2002 to November 2003, by means of manual captures (with a Shannon trap) and by CDC light traps. A total of 23,156 specimens of phlebotomines sandflies were collected in a remnant of the Atlantic rainforest, houses, and animal shelters. Lutzomyia complexa was the most prevalent species, with a frequency of $62.5 \%$ $(14,445 / 23,156)$, followed by Lutzomyia migonei, with $33.2 \%(7,677 / 23,156)$. No Lutzomyia longipalpis (the main vector of Leishmania chagasi in Brazil and the Americas) was found in the target area. Some specimens were dissected, but no Leishmania parasites were found.
\end{abstract}

Leishmaniasis; Psychodidae; Disease Vectors

\author{
Maria Rosimery de Carvalho 1 \\ Bruna Santos Lima 1 \\ José Ferreira Marinho-Júnior 1 \\ Fernando José da Silva 1 \\ Hélio França Valença 2 \\ Francisco de Assis Almeida 2 \\ Amilton Lopes da Silva 2 \\ Sinval Pinto Brandão-Filho 1
}

\section{Introduction}

American visceral leishmaniasis (AVL) is a zoonosis of domestic and wild canids and probably other wild mammals such as opossums and rodents. The disease is caused by Leishmania (Leishmania) chagasi (Kinetoplastida, Trypanosomatidae) and commonly transmitted by the phlebotomine sandfly Lutzomyia longipalpis (Diptera, Psychodidae), the main vector species incriminated in Brazil and the Americas 1. Until the 1970s, the zoonotic cycle of AVL was commonly associated with rural areas 2,3 . However, in the past 25 years there has been an urbanization of this disease in important cities of Northeast and Southeast Brazil, like Teresina (Piauí), São Luiz (Maranhão), Natal (Rio Grande do Norte), Campo Grande (Mato Grosso do Sul), and Belo Horizonte (Minas Gerais), and it has become a more important public health problem than ever before. Approximately 3,000 new cases of AVL are currently reported per year in Brazil, particularly in the Northeast, with some $77 \%$ of the cases 4 .

In Pernambuco, AVL is now present in almost all regions of the State, although most cases are from the Sertão (backlands) 5,6. In 1999 and 2000, twelve human cases of AVL were reported in São Vicente Férrer, a municipality (county) located in the northern Zona da Mata region near the Agreste region. Based on current knowledge, in the Zona da Mata in Pernambuco State, American cutaneous leishmaniasis caused by Leishmania 
(Viannia) braziliensis is the predominant form of leishmaniasis 7,8. Until recently, no autochthonous cases of the visceral form of leishmaniasis had been observed in the municipalities comprising the Zona da Mata region. In the coastal region, however, autochthonous cases of AVL have frequently been reported in municipalities like Ilha de Itamaracá, Paulista, Ipojuca, Tamandaré, and Rio Formoso, the first three located in Greater Metropolitan Recife (capital of Pernambuco State). This article presents data from a study on the phlebotomine sandfly fauna in Mundo Novo, a locality that recorded six of the 12 cases of AVL reported in São Vicente Férrer in 1999 and 2000. The aim is to identify species involved in the disease transmission in this region of Pernambuco, Northeast Brazil.

\section{Material and methods}

The study was carried out in the locality of Mundo Novo, municipality of São Vicente Férrer, located in the northern Zona da Mata region of Pernambuco, some $110 \mathrm{~km}$ from the State capital, Recife (Figure 1). The municipality has an area of
$120.2 \mathrm{~km}^{2}$, with a plant cover consisting predominantly of banana plantations, hence the area's nickname "Land of the Banana". Other crops like grapes and sugar cane have also been grown. There is also some remaining primary Atlantic rainforest. The climate, according to Köppen's classification, is As' type (tropical rain forest climate), with the dry season from September to February and the rainy season from March to August 9. According to the most recent census data, São Vicente Férrer has some 25,000 inhabitants. To date, six human cases of AVL have been reported in Mundo Novo, including one infant death. American cutaneous leishmaniasis has also been reported in São Vicente Férrer, including in Mundo Novo.

From December 2002 to November 2003, sandfly captures were performed monthly for four nights/month in households with reported human AVL cases, animal shelters near the houses, plantations, and remnants of the Atlantic rainforest. Captures were performed at dusk and during the night, from 6:00 PM to 6:00 AM the following day, using ten CDC light traps and manual captures with Castro aspirators and a Shannon trap, from 6:00 to 9:00 PM.
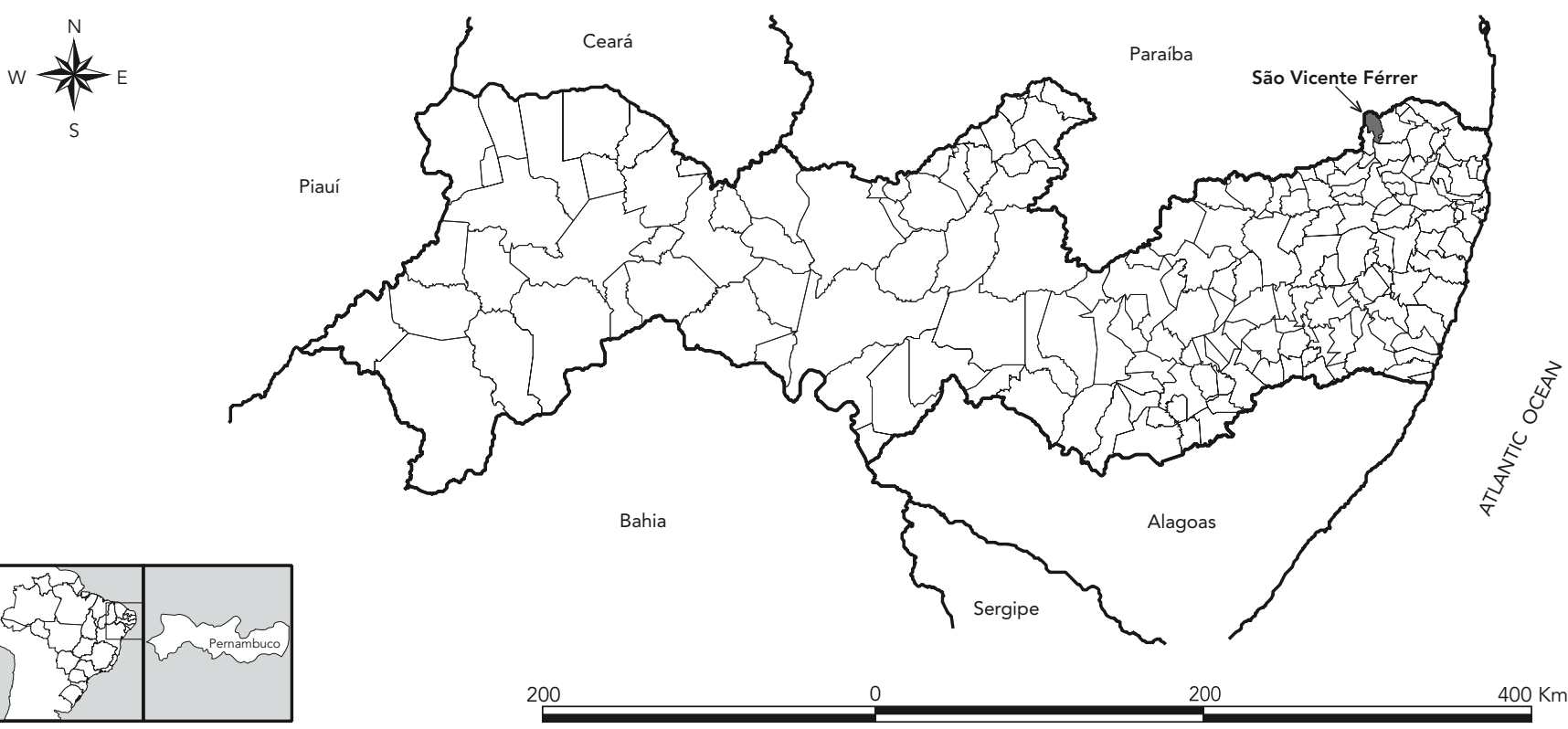
Specimens captured manually were kept in specific cages and transported to the laboratory, where they were dissected and identified. Female specimens were dissected in saline and the gut was examined to verify natural infection with Leishmania parasites. The specimens captured with light traps and males captured manually were preserved in $70 \%$ alcohol for identification, according to the classical Young \& Duncan systematics 10. Data were processed with Microsoft Excel for analysis of frequency distribution.

\section{Results}

A total of 23,156 specimens were collected, representing 16 species (Table 1). Lutzomyia complexa was the predominant species, with $62.5 \%$ $(14,481 / 23,156)$, followed by Lutzomyia migonei, with $33.1 \%(7,677 / 23,156)$. The latter species predominated in the houses and animal shelters with frequencies of $21.6 \%(1,658 / 7,677)$ and $75.6 \%(5,803 / 7,677)$, respectively, while $L$. complexa predominated in the remnants of Atlantic rainforest. Lutzomyia longipalpis, the proven main vector of AVL, was not found in this study. In relation to monthly sandfly density, the period with the greatest overall abundance of sandflies was from April to July. In relation to the main species, L. complexa was the most abundant from May to July, as was L. migonei from March to April (Figure 2). A total of 1,860 female specimens of different species were dissected during the study, but no natural infection with Leishmania parasites was observed.

\section{Discussion}

In the State of Pernambuco, AVL incidence has expanded in the last 15 years, with an increase in the number of reported cases, including those recently verified in the northern Zona da Mata, where no autochthonous cases had been recorded previously. The Zona da Mata has the majority of cases of American cutaneous leishmaniasis in the State, with some $60 \%$ of the total 7 . The phlebotomine sandfly fauna observed in the municipality of São Vicente Férrer presents an important diversity of species as compared to Amaraji, southern Zona da Mata, where L. whitmani, the main vector of $L$. (V.) braziliensis in Brazil, is the most prevalent sandfly species 11,12,13. American cutaneous leishmaniasis is the only form of leish-

Distribution of phlebotomine sandfly species according to capture site in Mundo Novo, São Vicente Férrer, Pernambuco, Brazil, from December 2002 to November 2003.

\begin{tabular}{|c|c|c|c|c|c|c|c|c|}
\hline \multirow[t]{3}{*}{ Species } & \multicolumn{6}{|c|}{ Capture site } & \multicolumn{2}{|c|}{ Total } \\
\hline & \multicolumn{2}{|c|}{ Animal shelters } & \multicolumn{2}{|c|}{ Houses } & \multicolumn{2}{|c|}{ Forest remnants } & \multirow[b]{2}{*}{$\mathrm{n}$} & \multirow[b]{2}{*}{$\%$} \\
\hline & $\mathrm{n}$ & $\%$ & $\mathbf{n}$ & $\%$ & $\mathrm{n}$ & $\%$ & & \\
\hline Lutzomyia complexa & 28 & 0.2 & 8 & 0.1 & 14,445 & 99.8 & 14,481 & 62.5 \\
\hline Lutzomyia migonei & 5,803 & 75.6 & 1,658 & 21.6 & 216 & 2.8 & 7,677 & 33.2 \\
\hline Lutzomyia evandroi & 121 & 37.2 & 169 & 52.0 & 35 & 10.8 & 325 & 1.4 \\
\hline Lutzomyia sordelli & 47 & 15.6 & 5 & 1.7 & 250 & 82.8 & 302 & 1.3 \\
\hline Lutzomyia naftalekatzi & & & & & 170 & 100.0 & 170 & 0.7 \\
\hline Lutzomyia shannoni & & & & & 38 & 100.0 & 38 & 0.2 \\
\hline Lutzomyia capixaba & & & & & 38 & 100.0 & 38 & 0.2 \\
\hline Lutzomyia whitmani & 34 & 91.9 & 3 & 8.1 & & & 37 & 0.2 \\
\hline Lutzomyia tupinamboi & & & & & 23 & 100.0 & 23 & 0.1 \\
\hline Lutzomyia quinquefer & 14 & 63.6 & 7 & 31.8 & 1 & 4.5 & 22 & 0.1 \\
\hline Lutzomyia furcata & & & & & 14 & 100.0 & 14 & 0.1 \\
\hline Lutzomyia fescheri & & & & & 10 & 100.0 & 10 & $<0.1$ \\
\hline Lutzomyia walkeri & & & & & 7 & 100.0 & 7 & $<0.1$ \\
\hline Lutzomyia brasiliensis & 2 & 50.0 & & & 2 & 50.0 & 4 & $<0.1$ \\
\hline Lutzomyia oswaldoi & & & & & 4 & 100.0 & 4 & $<0.1$ \\
\hline Lutzomyia choti & & & 1 & 50.0 & 1 & 50.0 & 2 & $<0.1$ \\
\hline Lutzomyia schreiberi & & & 1 & 50.0 & 1 & 50.0 & 2 & $<0.1$ \\
\hline Total & 6,049 & 26.1 & 1,852 & 8.0 & 15,255 & 65.9 & 23,156 & 100.0 \\
\hline
\end{tabular}


Monthly variation in the density of Lutzomyia complexa and Lutzomyia migonei in Mundo Novo,

São Vicente Férrer, Pernambuco, Brazil, from December 2002 to November 2003.

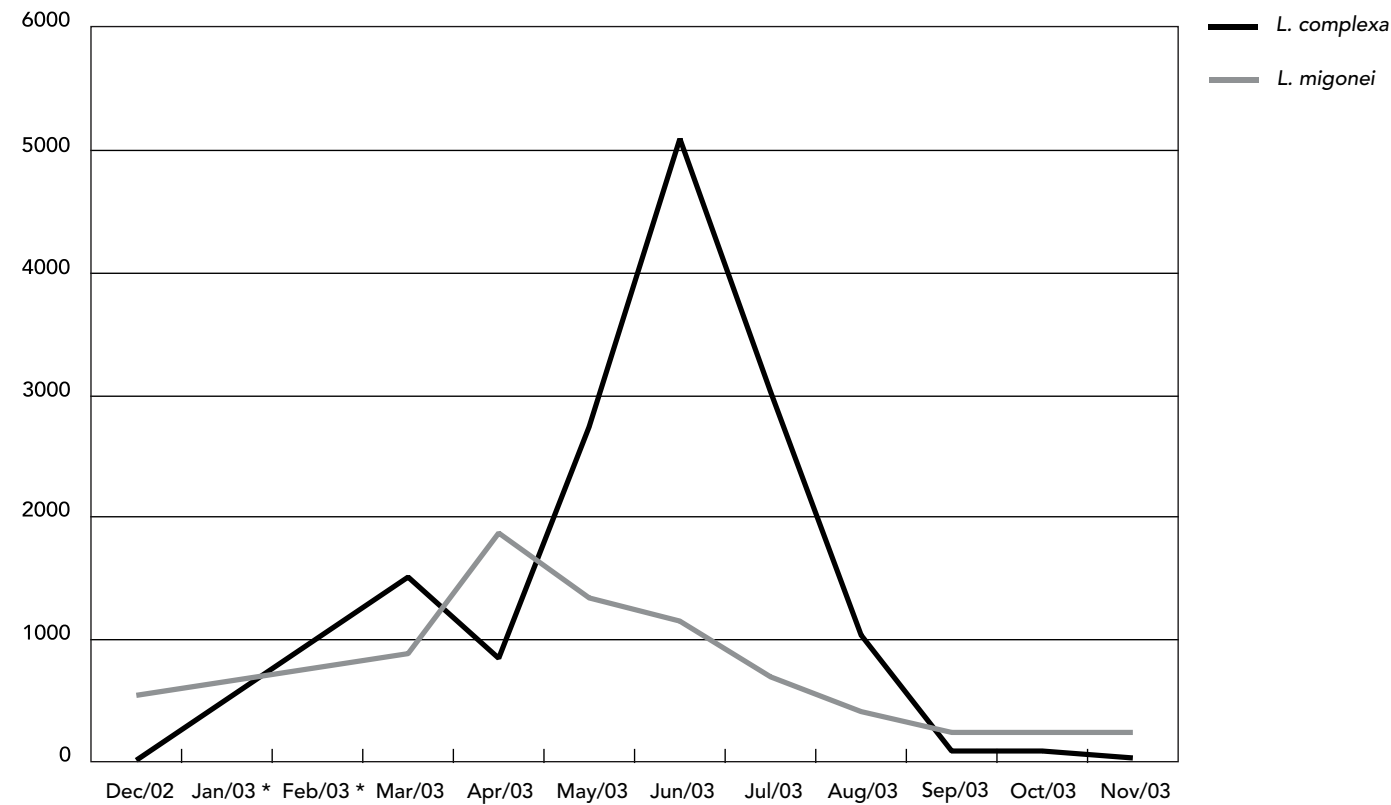

* No captures were performed from January to February 2003.

maniasis observed in this municipality, where we conducted a longitudinal study for some ten years $7,8,11$. The sandfly fauna in São Vicente Férrer is more similar to that in a military training area located in the central Zona da Mata. This area presents a more preserved plant cover than the remnant of Atlantic rainforest and has reported some outbreaks of cutaneous leishmaniasis 14,15.

A study on the prevalence of Leishmania infection in the human population in Mundo Novo using the delayed hypersensitivity test with Leishmania (Leishmania) amazonensis leishmanin produced by Bio-Manguinhos, Oswaldo Cruz Foundation, showed 35\% of positive reactions (unpublished data). Moreover, four strains of $L$. (L.) chagasi were obtained from dogs in this locality, whose samples were characterized by monoclonal antibodies and isoenzymes 16 . These data corroborate evidence regarding the high transmissibility and maintenance of both zoonotic cycles, i.e., American cutaneous leishmaniasis and American visceral leishmaniasis, in this region.

The most important finding from São Vicente Férrer is the absence of $L$. longipalpis, the prin- cipal vector incriminated in the AVL zoonotic transmission cycle 17 . Other sandfly species are suspected of acting as vectors in different areas of Brazil, such as L. cruzi in sites in Mato Grosso do Sul State 18 and L. migonei and L. firmatoi in the municipality of Rio de Janeiro 19. However, the presence of L. longipalpis has been recorded concomitantly in the same sites in Mato Grosso do Sul.

Our results show indirect evidence of the possible involvement of L. migonei and L. complexa as vectors in this area of Pernambuco, due to their abundance in the domiciliary environment and animal shelters in the peridomiciliary area (L. migonei) and remnants of Atlantic rainforest near plantations (L. complexa), although with no parasitological confirmation of natural infection (one of the main criteria for incriminating a given species as a proven vector). Our hypothesis is that L. migonei may be involved in the transmission of AVL and American cutaneous leishmaniasis in the domestic zoonotic cycle, while $L$. complexa, a proven vector of $L$. (V.) braziliensis 20 , could de involved in the forest environment. 
In conclusion, this study contributes to the knowledge of the phlebotomine sandfly fauna in the Zona da Mata region. We are developing further studies to reinforce the hypotheses presented above. These studies include the identification of reservoir hosts involved in maintaining the zoonotic and enzootic cycles in order to complement the characterization of the transmission pattern for both AVL and American cutaneous leishmaniasis in this endemic area of Northeast Brazil.

\section{Resumo}

Este estudo teve como objetivo identificar a fauna de flebotomíneos envolvida em área de incidência de leishmaniose visceral americana no Município de São Vicente Férrer, localizado na Zona da Mata de Pernambuco, Brasil. Capturas de flebotomíneos foram realizadas mensalmente durante quatro noites, entre dezembro de 2002 e novembro de 2003, através de capturas manuais com auxílio da armadilha de Shannon e armadilhas luminosas modelo CDC. O total de 23.156 exemplares de flebotomíneos foi coletado em resquícios de Mata Atlântica, casas e abrigos de animais. Lutzomyia complexa apresentou predominância de 62,5\% (14.445/23.156), seguida por Lutzomyia migonei, 33,2\% (7.677/23.156). Lutzomyia longipalpis, principal vetor de Leishmania chagasi no Brasile nas Américas, não foi encontrado nesta região. Alguns exemplares foram dissecados para a pesquisa de infecção natural, mas não foram detectadas formas características de Leishmania.

\section{Contributors}

M. R. Carvalho prepared the table and figures. B. S. Lima checked the bibliographic references. J. F. MarinhoJúnior participated in the sandfly identification. H. F. Valença participated in the sandfly dissection to investigate for natural infection. A. L. Silva, F. A. Almeida and F. J. Silva participated in the sandfly captures and identification of specimens. S. P. Brandão-Filho coordinated the study and wrote the article.

\section{Acknowledgements}

The authors wish to thank Filipe Dantas-Torres for assisting with the initial review of the English draft and Carlos Luna for preparing the figures. 


\section{References}

1. Lainson R, Shaw JJ. New World leishmaniasis: the neoptopical Leishmania species. In: Collier L, Balows A, Sussman M, editors. Topley \& Wilson's microbiology and microbial infectious diseases. 9th Ed. London: Arnold/New York: Oxford University Press; 1998. p. 241-66.

2. Deane LM. Leishmaniose visceral no Brasil: estudos sobre reservatórios e transmissores realizados no Estado do Ceará. Rio de Janeiro: Serviço Nacional de Educação Sanitária; 1956.

3. Lainson R. The American leishmaniases: some observations on their ecology and epidemiology. Trans R Soc Trop Med Hyg 1983; 77:569-96.

4. Dantas-Torres F, Brandão-Filho SP. Visceral leishmaniasis in Brazil: revisiting paradigms of epidemiology and control. Rev Inst Med Trop São Paulo 2006; 48:151-6.

5. Dantas-Torres F, Brandão-Filho SP. A leishmaniose visceral é uma doença endêmica em Recife, Pernambuco? Rev Soc Bras Med Trop 2005; 38:361-2.

6. Dantas-Torres F, Brandão-Filho SP. Expansão geográfica da leishmaniose visceral no Estado de Pernambuco. Rev Soc Bras Med Trop 2006, 39:352-6.

7. Brandão-Filho SP, Campbell-Lendrum DH, Brito MEF, Shaw JJ, Davies CR. Epidemiological surveys confirm an increasing burden of cutaneous leishmaniasis in Northeast Brazil. Trans R Soc Trop Med Hyg 1999; 93:488-94.

8. Brandão-Filho SP, Brito MEF, Carvalho FG, Ishikawa EA, Floetter-Winter LM, Shaw JJ. Wild and synanthropic hosts of Leishmania (Viannia) braziliensis in the endemic cutaneous leishmaniasis locality of Amaraji, Pernambuco State, Brasil. Trans R Soc Trop Med Hyg 2003; 97:291-6.

9. Pietrobom MR, Barros ICL. Pteridófitas de um remanescente de floresta Atlântica em São Vicente Férrer, Pernambuco, Brasil: Pteridaceae. Acta Bot Bras 2002; 16:457-79.

10. Young D, Duncan M. Guide to the identification and geographic distribution of Lutzomyia sand flies in Mexico, the West Indies, Central and South America (Diptera: Psychodidae). Gainesville: Associated Publishers; 1994.

11. Brandão-Filho SP, Carvalho FG, Brito MEF Almeida FA, Nascimento LA. American cutaneous leishmaniasis in Pernambuco, Brazil: eco-epidemiological aspects in "Zona da Mata" region. Mem Inst Oswaldo Cruz 1994; 89:445-9.
12. Campbell-Lendrum DH, Brandão-Filho SP, Ready P, Davies CR. Host and/or site loyalty of Lutzomyia whitmani (Diptera: Psychodidae) in Brazil. Med Vet Entomol 1999; 13:209-11.

13. Brandão-Filho SP. Eco-epidemiologia da leishmaniose tegumentar americana associada a Leishmania (Viannia) braziliensis na Zona da Mata Atlântica do Estado de Pernambuco, Brasil [PhD Dissertation]. São Paulo: Universidade de São Paulo; 2001.

14. Brandão-Filho SP, Brito MEF, Martins CAP, Sommer IB, Valença HF, Almeida FA, et al. Leishmaniose tegumentar americana em centro de treinamento militar localizado na Zona da Mata de Pernambuco, Brasil. Rev Soc Bras Med Trop 1988; 31:575-8.

15. Andrade MS, Valença, HF, Silva AL, Almeida FA, Almeida EL, Brito MEF, et al. Sandfly fauna in a military training area endemic for American tegumentary leishmaniasis in the Atlantic Rain Forest region of Pernambuco, Brazil. Cad Saúde Pública 2005; 21:1761-7.

16. Carvalho MR. Eco-epidemiologia da leishmaniose visceral americana na Zona da Mata de Pernambuco, Brasil [Master's Thesis]. Recife: Centro de Pesquisas Aggeu Magalhães, Fundação Oswaldo Cruz; 2005.

17. Lainson R, Rangel EF. Lutzomyia longipalpis and the eco-epidemiology of American visceral leishmaniasis, with particular reference to Brazil - a review. Mem Inst Oswaldo Cruz 2005; 100:811-27.

18. Santos SO, Arias JR, Ribeiro AA, Hoffmann MP, Freitas RA, Malacco MAF. Incrimination of Lutzomyia cruzi as a vector of American visceral leishmaniasis. Med Vet Entomol 1998; 12:315-7.

19. Souza MB, Marzochi MCA, Carvalho RW, Ribeiro PC, Pontes CS, Caetano JM, et al. Ausência da Lutzomyia longipalpis em algumas áreas de ocorrência de leishmaniose visceral no Município do Rio de Janeiro. Cad Saúde Pública 2003; 19:1881-5.

20. Souza A, Ishikawa E, Braga R, Silveira F, Lainson R, Shaw JJ. Psychodopygus complexus, a new vector of Leishmania braziliensis to humans in Pará State, Brazil. Trans R Soc Trop Med Hyg 1996; 90:112-3.

Submitted on 29/Mar/2006

Final version resubmitted on $24 / \mathrm{Jul} / 2006$

Approved on 11/Aug/2006 